\title{
Effect of temperature on o-cresol methylation in a fluidized bed of commercial iron-chromium catalyst TZC-3/1
}

\author{
Gabriela Berkowicz, Witold Żukowski, Jerzy Baron \\ Cracow University of Technology, Department of Inorganic Chemistry and Technology, ul. Warszawska 24, \\ 31-155 Cracow, Poland \\ * Corresponding author: e-mail: gberkowicz@chemia.pk.edu.pl
}

\begin{abstract}
The paper presents the results of the synthesis of 2,6-dimetyhlphenol (26DMP) from o-cresol. The target compound is an important substrate for polymer chemistry. Due to a large amount of o-cresol which is generated as a by-product, during the synthesis of 2,6-dimethylphenol from phenol, the methylation of o-cresol to 2,6-dimethylphenol should be examined as a separate process. The alkylation of o-cresol was carried out in a fluidized bed of commercial iron-chromium catalyst TZC-3/1. Undesirable decomposition of methyl alcohol on the catalyst generates a number of environmentally dangerous by-products such as methane, carbon dioxide, carbon monoxide. The effect of temperature on the yield of the synthesis was investigated. The synthesis process was monitored on-line in the temperature range $310-380^{\circ} \mathrm{C}$, completely covering the maximum efficiency of the process. Online analysis of the process by FTIR spectroscopy gave information about products of both methylation of o-cresol and pyrolysis of methanol. The maximum $85 \%$ yield of desired 2,6-dimethylphenol with more than $85 \%$ conversion of o-cresol was achieved at $340^{\circ} \mathrm{C}$, at 1:6 molar ratio of o-cresol:methanol.
\end{abstract}

Keywords: 2,6-dimethylphenol, o-cresol methylation, iron-chromium catalyst TZC-3/1, fluidized bed.

\section{INTRODUCTION}

The synthesis of 2,6-dimethylphenol is an object of interest of many scientists ${ }^{1-5}$, mainly because of its use in plastics industry. The lack of free ortho-positions in a molecule of phenol derivative causes that during the polycondensation, molecules are combined in a para-position $^{6}$. In such a way the linear molecule of polyphenylene oxide (PPO) is formed. This polymer is characterized by high mechanical and thermal resistance, low water absorption, low coefficient of linear expansion, fire resistance, low variation of dielectric properties ${ }^{7}$. Moreover, PPO perfectly blends with another polymer in different molar ratios. These properties make it an ideal material, among others, for the automotive industry?

Applications of PPO/PS blends include mainly large parts such as fenders, wheel covers, elements of motor-car body. The synthesis of polyphenylene oxide is, without doubt, the most important application of 2,6-dimethylphenol, but not the only one. This di-methyl derivative of phenol is also used for the production of medicines ${ }^{8}$, dyes $^{8-9}$ and antioxidants ${ }^{10}$.

It has been observed, that the alkylation of phenol with methyl alcohol on iron-chromium catalyst leads selectively to ortho-substituted derivatives ${ }^{11}$. However, o-cresol, the first product of the methylation of phenol, takes a significant part in the production of 2,6-dimethylphenol synthesis. Previous studies have shown that operations such as the rise in temperature or increasing the amount of methanol are not satisfactorily effective in order to increase the reaction rate ${ }^{12}$.

Nevertheless, o-cresol should not be regarded as a waste, because it is an intermediate product in the synthesis of 2,6-dimethylphenol. Thus it becomes necessary to examine the alkylation of o-cresol with methyl alcohol on the TZC-3/1 catalyst as a separate, additional process.

\section{EXPERIMENTAL PART AND RESULTS}

The methylation of o-cresol was carried out in a fluidized bed of $100 \mathrm{~g}$ of iron-chromium catalyst - TZC-3/1, which is a commercial product of Zakłady Azotowe w Tarnowie-Mościcach Z.A. The active form of the catalyst is composed of $\mathrm{Fe}_{3} \mathrm{O}_{4}(72-90 \% \mathrm{~m} / \mathrm{m}), \mathrm{Cr}_{2} \mathrm{O}_{3}\left(7-11 \%_{\mathrm{m} / \mathrm{m}}\right)$, $\mathrm{CrO}_{3}\left(0-0.95 \%_{\mathrm{m} / \mathrm{m}}\right)$, and $\mathrm{CuO}\left(1.5-4.0 \%_{\mathrm{m} / \mathrm{m}}\right)$.

The process of fluidization of the TZC-3/1 catalyst has been previously studied, thus, the choice of an appropriate fraction of catalyst particles was made using the previously studied fluidization properties of this material $^{13}$. The process of o-cresol alkylation was monitored online using the FTIR spectrometer. Methylation was carried out in a temperature range from 300 to $380^{\circ} \mathrm{C}$, with the relatively small accretion (approximately 1.1 $\mathrm{K} / \mathrm{min}$ ) and analysis of the composition of the products was performed in a gaseous sample directly derived from gases leaving fluidized bed, every $\sim 23$ seconds - these conditions allow to regard the particular analysis as a result of the process carried out at constant temperature.

The alkylation of o-cresol was performed with 6 molar excess of methyl alcohol in relations to the aromatic substrate. The mixture of substrates also contained small amounts of water, which prevents the deposition of coke on the catalyst ${ }^{14}$. Gaseous products of reaction were appropriately diluted for the requirements of the FTIR analysis, and did not cause the condensation of any products of the process. A scheme of the test bench is shown in Figure 1.

The mixture of $56.0 \mathrm{mmol}$ of o-cresol, $336.2 \mathrm{mmol}$ of methyl alcohol and also $56.1 \mathrm{mmol}$ of water was dosed per hour into the fluidized bed reactor in a liquid form, later than vaporized and passed through the fluidized bed. Molar flow rates of the products leaving the fluidized bed are shown in form of graphs in Figure 2 as a function of bed temperature. The maximum efficiency of 2,6-dimethylphenol synthesis was achieved at $340^{\circ} \mathrm{C}$. 


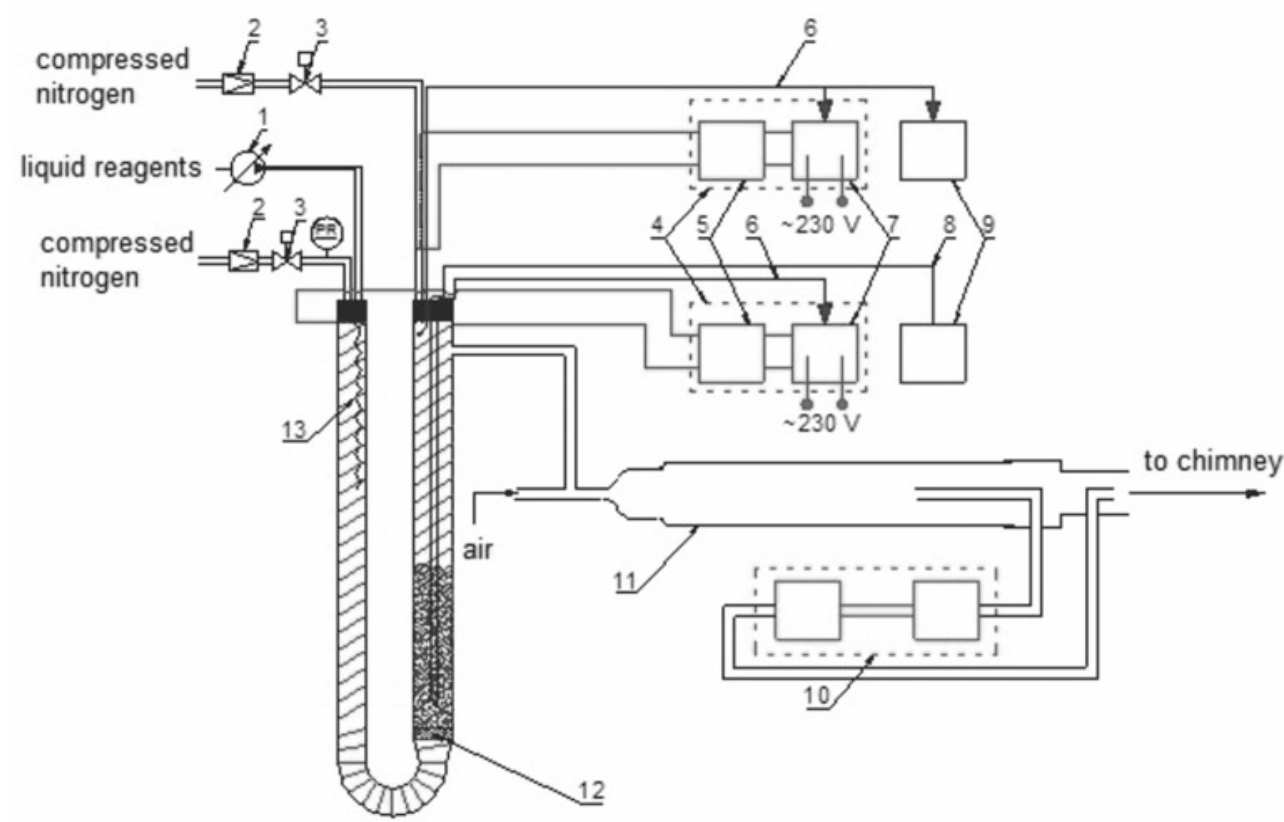

1 - infusion pump, 2 - reducing valve, 3 - reducing valve, 4 - temperature control, 5 - semiconductor transmitter RP6, 6 - regulatory thermocouple, 7 - regulator PID 23PL, 8 - control thermocouple, 9 - recorders, 10 - FT-IR, 11 - dilution chamber, 12 - distributor, 13 - vaporizer

Figure 1. Experimental set-up for o-cresol methylation by methanol in the catalytic fluidized bed
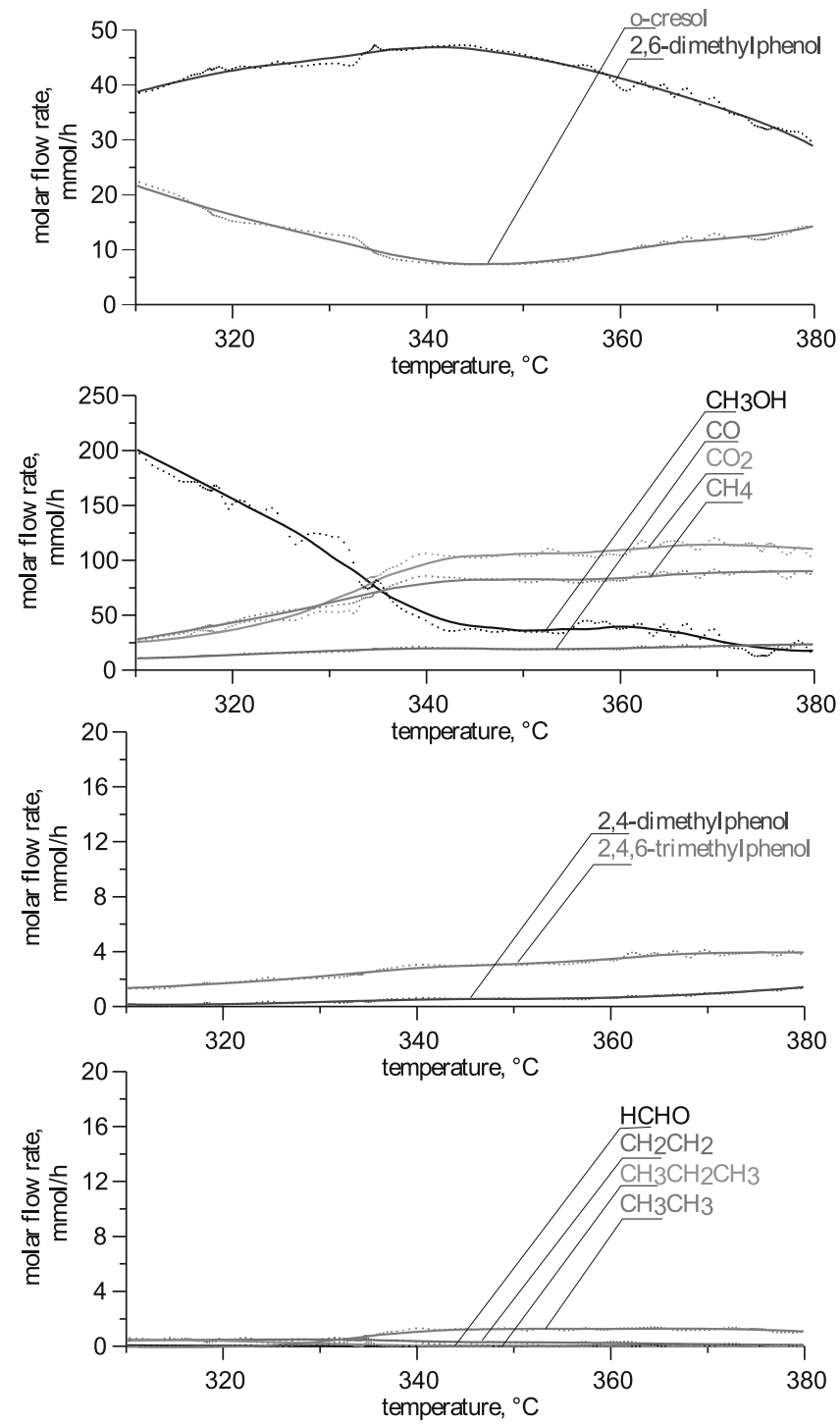

Figure 2. Molar flow rates of unreacted o-cresol, methanol, alkylation products and by-products as functions of bed temperature
The total amount of by-products (2,4-dimethylphenol and 2,4,6-trimethylphenol) at this temperature was 14 times lower than the amount of the target compound. Above $350^{\circ} \mathrm{C}$ the concentration of the aromatic substrate was increasing again. This is because of the lack of methanol, which is intensely decomposed in a competitive reaction of its pyrolysis. The problem of methanol decomposition during phenol or o-cresol methylation is often omitted in the literature, probably due to the difficulties of measurement of gaseous products concentration. Only a few papers take notice of this problem ${ }^{\mathbf{1 5 - 1 7}}$. The decomposition of methyl alcohol on the catalyst generates a number of by-products such as methane, carbon dioxide, carbon monoxide. The ability to absorb electromagnetic radiation in the IR range by these gases causes that the method of FTIR analysis of this chemical process also allowed us to establish the quantities of gases from methanol decomposition. The ratio of the generated carbon monoxide and hydrogen can enable to use them for the production of hydrocarbons in the Fischer - Tropsch process. On the other hand, methanol decomposition is also important because of the generation of hydrogen possible alternative source of energy ${ }^{18-20}$.

The degree of o-cresol conversion, the yield and selectivity of target 2,6-dimethylphenol are shown in Table 1. Almost an $85 \%$ yield of 2,6-dimethylphenol with more than $85 \%$ conversion of o-cresol was obtained at $340^{\circ} \mathrm{C}$. The obtained results of the process synthesis suggest that an increase in methanol excess in relation to the aromatic substrate is not necessary. Satisfactory efficiency of the desired compound with a high degree of purity of the main product was achieved.

\section{CONCLUSIONS}

The alkylation of o-cresol with methanol can be efficiently carried out on the commercial iron-chromium catalyst TZC-3/1. The use of the catalyst in the form of 
Table 1. Absorption and emission data for the studied systems

\begin{tabular}{|l|c|c|c|}
\hline \multirow{2}{*}{$\begin{array}{l}\text { Temperature of } \\
\text { fluidized bed }\end{array}$} & $\begin{array}{c}\text { Conversion } \\
\text { of o-cresol }\end{array}$ & $\begin{array}{c}\text { Yield of } \\
\text { 26DMP }\end{array}$ & $\begin{array}{c}\text { Selectivity of } \\
\text { 26DMP }\end{array}$ \\
\cline { 2 - 4 } & \multicolumn{3}{|c|}{$[\%]$} \\
\hline $310^{\circ} \mathrm{C}$ & 61.39 & 69.16 & 96.27 \\
\hline $315^{\circ} \mathrm{C}$ & 66.52 & 73.16 & 96.11 \\
\hline $320^{\circ} \mathrm{C}$ & 71.03 & 76.22 & 95.80 \\
\hline $325^{\circ} \mathrm{C}$ & 75.12 & 78.32 & 95.29 \\
\hline $330^{\circ} \mathrm{C}$ & 78.96 & 80.28 & 94.66 \\
\hline $335^{\circ} \mathrm{C}$ & 82.79 & 82.46 & 93.98 \\
\hline $340^{\circ} \mathrm{C}$ & 85.74 & 83.67 & 93.38 \\
\hline $345^{\circ} \mathrm{C}$ & 86.77 & 82.93 & 92.93 \\
\hline $350^{\circ} \mathrm{C}$ & 86.40 & 80.57 & 92.44 \\
\hline $355^{\circ} \mathrm{C}$ & 84.90 & 77.44 & 91.89 \\
\hline $360^{\circ} \mathrm{C}$ & 82.22 & 73.28 & 90.81 \\
\hline $365^{\circ} \mathrm{C}$ & 80.03 & 68.85 & 89.47 \\
\hline $370^{\circ} \mathrm{C}$ & 78.71 & 64.24 & 88.16 \\
\hline $375^{\circ} \mathrm{C}$ & 77.09 & 58.45 & 86.55 \\
\hline $380^{\circ} \mathrm{C}$ & 74.33 & 51.22 & 84.22 \\
\hline
\end{tabular}

a fluidized bed leads to high efficiency and easy temperature control of the process. The analysis of the process by FTIR spectrometer and carrying out the process with a minimal accretion of temperature gave precise data of the process in the tested temperature range. At the stage of the current research, the synthesis of 2,6-dimethylphenol carried out at $340^{\circ} \mathrm{C}$ and in 6 molar excess of methanol in relation to o-cresol is considered as the best in terms of the yield and selectivity of the desired 2,6-dimethylphenol. The target compound was obtained with almost $85 \%$ yield and with more than $85 \%$ conversion of o-cresol.

\section{LITERATURE CITED}

1. Grabowska, H., Kaczmarczyk, W. \& Wrzyszcz, J. (1989). Synthesis of 2,6-Xylenol by Alkylation of Phenol with Methanol. Appl. Catal. Gen. 47 (2), 351-355. DOI: 10.1016/S01669834(00)83240-6.

2. Leach, B.E. \& Starks, C.M. (1976). U.S. Patent No. 3,996,297. U.S. Patent and Trademark Office.

3. Frabetti, A.J. (1977). U.S. Patent No. 4,041,085. U.S. Patent and Trademark Office.

4. Klimkiewicz, R., Grabowska, H., Teterycz, H., Licznerski, B.W., Nitsch, K. \& Wiśniewski, K. (2008). PL Patent No. 198595 B1.

5. Caruso, A.J. \& Lee, J.L. (1995). U.S. Patent No. 5,475,156. U.S. Patent and Trademark Office.

6. Hay, A.S. (1999). Poly(phenylene oxide)s and poly(arylene ether)s derived from 2,6-diarylphenols. Progr. Polymer. Sci. 24 (1), 45-80. DOI: 10.1016/S0079-6700(98)00016-1.

7. Dobrosz, K. \& Matysiak, A. (1982). Plastics in automotive vehicles. Warszawa. Wydawnictwa Komunikacji i Łączności. [in Polish: Tworzywa sztuczne w pojazdach samochodowych].

8. Deepak Novochem Technologies Limited. (2010). Retrieved February 14, 2013, from http://www.dntl.co.in/dyes-category-4/2,6_xylenol-product-4.htm

9. Pospíšilová, M., Svobodová, D., Gasparič, J. \& Macháček, M. (1990). Investigation of the colour reaction of phenols with MBTH, II: Properties of the isolated products of the reaction with phenol, 2,6-dimethylphenol and 4-methylphenol. Microchim. Acta 102 (1-3), 117-128. DOI: 10.1007/BF01244294.

10. Kemeleva, E.A., Vasiunina, E.A., Sinitsyna, O.I., Khomchenko, A.S., Gross, M.A., Kandalintseva, N.V., Prosenko, A.E. \& Nevinskiı̆, G.A. (2008). New promising antioxidants based on 2,6-dimethylphenol. Russ. J. Bioorg. Chem. 34 (4), 499-509. DOI: $10.1134 /$ S106816200804016X.

11. Jamanek, D., Zielecka, M., Wielgosz, Z., Cyruchin, K., Górska, A., Krakowiak, J. \& Lukomska, A. (2012). Fluidized bed application in synthesis of 2,6-dimethylphenol. Retrieved from http://ena.lp.edu.ua:8080/bitstream/ntb/13586/1/61_68-68Volume_6_1.pdf

12. Baron, J., Berkowicz, G., Żukowski, W., Kandefer, S., Szarlik, S., Zielecka, M., Wielgosz, Z. \& Jamanek, D. (2012). Study of decomposition of methanol during C-alkylation of phenol with methyl alcohol. 24-27 September 2012, 66-67. 3rd Workshop Green Chemistry and Nanotechnologies in Polymer Chemistry. Cracow.

13. Baron, J., Berkowicz, G., Żukowski, W., Kandefer, S., Szarlik, S., Zielecka, M., Wielgosz, Z. \& Jamanek, D. (2012). 8-12 July 2012, 396. Study of fluidization of TZC-3/1 catalyst powders under different conditions. Materiały Kongresowe 7 Kongres Technologii Chemicznej. Cracow. [in Polish: Badanie fluidyzacji proszków katalizatora TZC 3/1 w różnych warunkach modelowych].

14. Biały, J., Penczek, I., Kopytowska, N., Wrzyszcz, J. \& Kulak, S. (1980). PL Patent No. 105922.

15. Li, K.T., Wang, I. \& Chang, K.R. (1993). Methylation of phenol to 2,6-dimethylphenol on a manganese oxide catalyst. Ind. Eng. Chem. Res. 32, 1007-1011. DOI: 10.1021/ie00018a002.

16. Sato, S., Koizumi, K. \& Nozaki, F. (1998). Ortho-Selective Methylation of Phenol Catalyzed by $\mathrm{CeO}_{2}-\mathrm{MgO}$ Prepared by Citrate Process. J. Catal. 178, 264-274. DOI: 10.1006/ jcat.1998.2159.

17. Durgakumari, V., Narayanan, S. \& Molec, J. (1991). A comparative study of oxides for m-cresol alkylation. Catal. 65 , 385-392. DOI: 10.1016/0304-5102(91)85073-B.

18. Brown, J.C. \& Gulari, E. (2004). Hydrogen production from methanol decomposition over $\mathrm{Pt} / \mathrm{Al}_{2} \mathrm{O}_{3}$ and ceria promoted Pt/ $\mathrm{Al}_{2} \mathrm{O}_{3}$ catalysts. Catal. Comm. 5, 431-436. DOI: 10.1016/j. catcom.2004.05.008.

19. Choi, Y. \& Stenger, H. (2002). Kinetics of methanol decomposition and water gas shift reaction on a commercial $\mathrm{Cu}-\mathrm{ZnO} / \mathrm{Al}_{2} \mathrm{O}_{3}$ catalyst. Preprint Paper Am Chem Soc Div Fuel Chem. 47 (2), 723-724

20. Rozovskii, A.Y. \& Lin, G.I. (2003). Fundaments of Methanol Synthesis and Decomposition. Top. Catal. 22 (3-4), 137-150. DOI: 10.1023/A:1023555415577. 